INOBIS: Jurnal Inovasi Bisnis dan Manajemen Indonesia

Volume 2, Nomor 1, Desember 2018

Vinna Hermaren; Adrian Achyar

\title{
The effect of firm created content and user generated content evaluation in social media on customer-based brand equity
}

\author{
Vinna Hermaren \\ Adrian Achyar \\ Department of Management, University of Indonesia, Salemba 10430, Indonesia \\ E-mail: vhermaren@yahoo.com
}

\begin{abstract}
The purpose of this paper is to investigate social media communication and its impact on customer-based brand equity. Compare two social media communication tools that are firm created content and user generated content. A total of 114 data sets developed through a standard online survey to investigate the impact of firm created content and user-generated content evaluation in social media on brand awareness / association, perceived quality and brand loyalty to the cosmetics industry in Indonesia. A mini survey was conducted to find out the types of cosmetic brands that do not perform ad campaigns in traditional media such as television to see clearly the influence of brand communication in social media against brand awareness and association. The author applies Structural Equation Modeling (SEM) techniques to investigate the effect of communication on social media on customer-based brand equity. The findings of this study indicate that evaluation of firm created content has a positive and significant impact on brand association / awareness, perceived quality and brand loyalty. Meanwhile, evaluation of user-generated content has significant effect only on brand awareness / association and perceived quality. In the dimensions of customer-based brand equity, only perceived quality is significantly influenced by brand awareness / association. This research is relevant for marketers for the development of corporate strategy, especially in the cosmetics industry that uses social media as a medium of communication to customers.
\end{abstract}

Keywords : Marketing, Firm created content, User generated content, Customer based brand equity, SEM

\section{Introduction}

The Internet has evolved into a different medium than was predicted 10 years ago. Currently more than 3 billion people use the internet worldwide and its growth since 2005 is staggering. Here's data on the number of internet users in worldwide from 2005 to 2017:

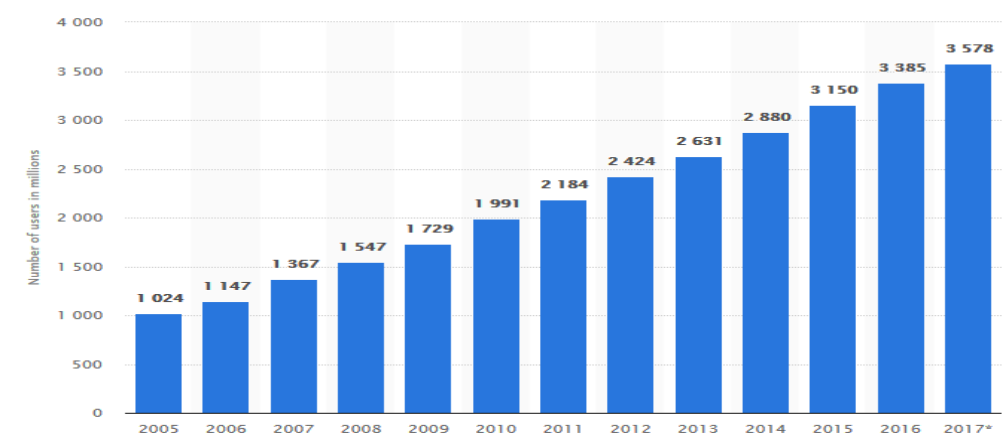

Figure 1.1 Data on the number of Internet users worldwide

Source: https://www.statista.com/statistics/273018/number-of-internet-users-worldwide/ 
INOBIS: Jurnal Inovasi Bisnis dan Manajemen Indonesia

Volume 2, Nomor 1, Desember 2018

Vinna Hermaren; Adrian Achyar

Some of the reasons why this growth is so fast one of them is because of the increasing desire of consumers for the information they can now get easily, the speed and convenience of obtaining this information, as well as the ability to control what and how much they receive. In terms of marketers, the Internet is considered attractive because of its ability to target customers effectively. The Internet is also a medium that will provide faster feedback on the value of marketing expenditures, customer satisfaction, trends, and competition (Belch \& Belch, 2015).

By 2016, social media is the most accessible internet content in Indonesia by 129.2 million people or $97.4 \%$ of total internet users in Indonesia of 132.7 million people or $51.8 \%$ of the total population (APJII, 2016). The following data types of internet content are often accessed in Indonesia:

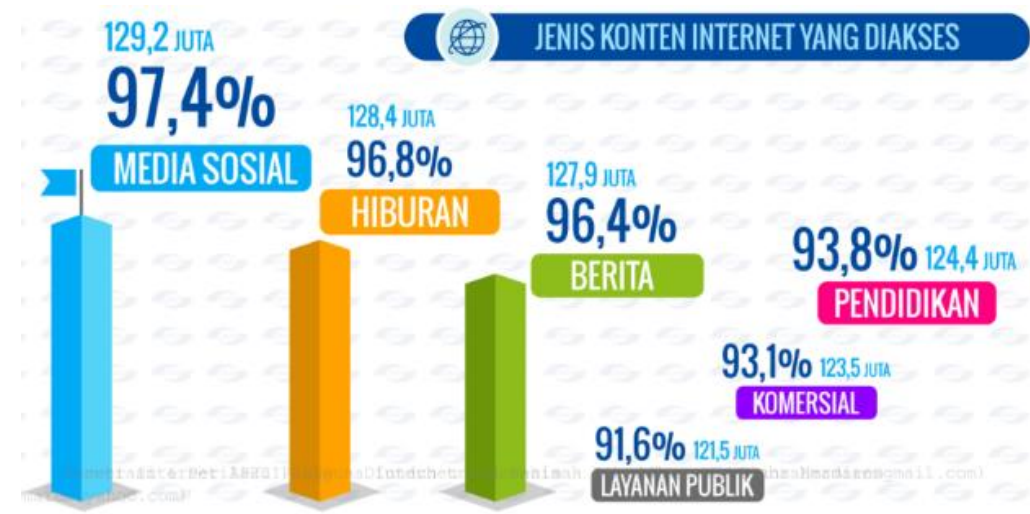

Figure 1.2 Type of Internet content accessed

Source: APJII, 2016

Social media is a group of internet-based applications that build the foundation of ideology and Web 2.0 technology and enable the creation and exchange of user generated content (Kaplan \& Haenlein, 2010). User generated content is publicly available content on the Internet that reflects a number of creative endeavors and is created outside of professional routines and practices (OECD, 2007).

Social media has exploded as an online discourse category where people can create content, share, bookmark and network at an incredible rate (Asur \& Huberman, 2010). Interestingly, social media is not really a new phenomenon. Online social interaction has been around since the beginning. But what has changed in recent years is the reach and penetration of these social media technologies, their adoption into everyday life, and the development of user generated content and peer-to-peer interactions resulting from it (Ryan \& Jones, 2009).

Various academic researchers and practitioners are interested in social media especially in terms of challenges and opportunities for brand management processes (Grubor, Djokic, \& Milovanov, 2017). According to Fournier \& Avery (2011) and Muniz \& Schau (2011), social media helps boost sales, engage consumers in the brand creation process, expand brand awareness, provide more positive associations and increase consumer loyalty to brands. While creating great opportunities, social media also poses challenges for the company. Specifically related to user generated content. Social media allows users to create positive and negative influences on brand equity (Khajuria, 2017). This is because user generated content can not be controlled by the company. Therefore, many researchers advise marketers to get involved in social media (Khajuria, 2017, Ryan \& Jones, 2009). The company's corporate page on social 
INOBIS: Jurnal Inovasi Bisnis dan Manajemen Indonesia

Volume 2, Nomor 1, Desember 2018

Vinna Hermaren; Adrian Achyar

media can be used to establish relationships and communicate with consumers. This form of communication is called firm created content where companies can create and control content and conversations in social media (Schivinski \& Dabrowski, 2015).

The form of corporate fan pages on social media has been widely used by companies in various industries. One industry that utilizes social media is the cosmetics industry. In Indonesia, the cosmetics industry is one of the 11 main industry sectors that are the government's priority because it plays a major role as the prime mover of the economy (Government Regulation No. 14 of 2015 on the National Industrial Development Master Plan (RIPIN) 2015-2035). The Ministry of Industry said the industry value is estimated to reach 100 trillion rupiah. This is driven by the growth of middle class society which in volume of demand for cosmetics from this segment is very large. In addition, in 2035 the population of Indonesia is projected to penetrate the number 305.6 million (Bappenas, 2014). This figure increased $19.28 \%$ from 2016 where the population is about 256.2 million inhabitants.

With 760 large, medium and small scale cosmetic companies scattered in Indonesia territory raises competition for consumers (kemenperin.go.id). Promotional strategies no longer focus only on traditional media such as television, but also utilize social media to make consumers aware of the brand and can establish relationships that create consumer loyalty. According to Head of Research NH Korindo Reza Priyambada cited by duniaindustri.com, cosmetic products usually have target customers who tend to be loyal to a particular brand.

Several studies have been conducted related to social media communication and brand management. Some of these are studies conducted by Schivinski \& Dabrowski (2015) on the impact of brand communications on brand equity through Facebook. Brand equity is a brand asset or liability associated with a brand name and a symbol that is able to increase or decrease the value of a given product or service. Brand awareness, brand association, perceived quality and brand loyalty are the dimensions that make up brand equity (Aaker, 2000).

There is a literature gap on issues and challenges faced in using social media communications especially to brand equity both in industry and the type of social media used. In addition, the study of firm created content and user generated content on brand equity is very rare in Indonesia so that this study aims to highlight issues and challenges of social media communication, both firm genareted content and user generated content in increasing brand equity in the cosmetics industry in Indonesia.

This study uses quantitative analysis by distributing an online questionnaire to 114 respondents Emina Cosmetics consumers who only see the Emina Cosmetics ads in social media and has followed the social media Emina Cosmetics official. The result of quantitative analysis is discussed to get the perspective of Emina Cosmetics consumer about brand awareness / association, perceived quality and brand loyalty caused by communication done in social media.

\section{Definitions and Dimensions of Social Media Communication and Customer-Based Brand Equity}

Studies have shown that consumers consider social media as more trustworthy sources of information than the traditional instruments of marketing communications used by companies (Karakaya and Barnes, 2010). Thus, marketing and brand managers may assume that brand communication will increase through user-generated social media communication (Smith et al., 2012). To examine the impact of social media brand communications, it is necessary to distinguish between two different forms of them: firm-created and user-generated 
INOBIS: Jurnal Inovasi Bisnis dan Manajemen Indonesia

Volume 2, Nomor 1, Desember 2018

Vinna Hermaren; Adrian Achyar

social media communication (Godes and Mayzlin, 2009). This distinction between communication sources is relevant because firm-created social media communication is under the management of companies, while user-generated social media communication is independent of the firm's control (Vanden Bergh et al., 2011).

Customer-based brand equity is evaluating the consumer's response to a brand name (Keller 1993, Shocker et al. 1994). various researches in brand equity through the years result in all different kinds of dimension of brand equity that can be linked to a brand. However, the common denominator in all models is the utilization of one or more dimension of the Aaker model (Keller 1993; Motameni and Shahrokhi 1998; Yoo and Donthu 2001; Bendixen et al. 2003; Kim et al. 2003). Therefore, the consumer-based brand equity is an asset of four dimensions that are brand awareness, brand associations, perceived quality and brand loyalty.

Keller (2003, p.76) defines awareness as "the customers' ability to recall and recognize the brand as reflected by their ability to identify the brand under different conditions and to link the brand name, logo, symbol, and so forth to certain associations in memory". Aaker (1996) identifies other higher levels of awareness besides recognition and recall (Aaker 1991). He includes top of-mind, brand dominance, brand knowledge and brand opinion. Brand knowledge is the full set of brand associations linked to the brand (Keller, 1993).

A brand association is the most accepted aspect of brand equity (Aaker 1992). Associations represent the basis for purchase decision and for brand loyalty (Aaker 1991, p. 109). Brand associations consist of all brand-related thoughts, feelings, perceptions, images, experiences, beliefs, attitudes (Kotler and Keller 2006, p. 188) and is anything linked in memory to a brand. Empirical evidence show that brand awareness and brand associations can be combined into a particular dimension named brand awareness/associations (Yoo, Boonghee; Donthu, 2001).

Perceived quality is the customer's judgment about a product's overall excellence or superiority that is different from objective quality (Zeithaml 1988, pp. 3 and 4). Objective quality refers to the technical, measurable and verifiable nature of products/services, processes and quality controls.

Loyalty is a core dimension of brand equity. Aaker (1991, p.39) defines brand loyalty as the attachment that a customer has to a brand.

As mentioned earlier, this study was conducted with the aim to see whether social media communications, firm created content and user generated content, will be able to increase customer-based brand equity dimensions. A series of hypotheses were built to answer these questions based on previous research.

Brand awareness is the power of brand presence in the minds of consumers. Brand association has any brand-related meaning, including image formation by consumers, product profile, consumer condition, corporate awareness, brand characteristics, signs and symbols (Aaker and Joachimsthaler, 2000). According to empirical evidence shown Yoo et al. (2000) that brand awareness and brand association can be combined into one particular dimension of Brand awareness / association.

Previous research conducted by Bruhn et al. (2012) said the perception of communication in the context of brand communication in social media positively influence the perception of individuals towards the brand. There is a strong correlation between consumer engagement and fan brand page on facebook and their perception of brand awareness (Hutter et al., 2013). From these studies, researchers assume that there is a positive influence of brand communication in social media against brand awareness / association. The first hypothesis in this study is as follows:

H1a: Firm-created Content positively affects Brand Awareness / Association 
INOBIS: Jurnal Inovasi Bisnis dan Manajemen Indonesia

Volume 2, Nomor 1, Desember 2018

Vinna Hermaren; Adrian Achyar

\section{H1b: User Generated Content positively affects Brand Awareness / Association}

According to Aaker (1991), perceived quality can be interpreted as consumer perception of the overall quality or superiority of a product or service with respect to its purpose. Research shows that there is a positive relationship between advertising spending and brand quality perceptions (Villarejo-Ramos and Sancez-Franco, 2005). According to research conducted by Bashir \& Job (2017) there is a positive relationship between firm created content and perceived quality. Meanwhile, according to Schivinski \& Dabrowski (2015) in brand communication in social media, user generated content has a positive impact on perceived quality. So the second hypothesis in this study is as follows:

H2a: Firm-created content evaluation has a positive effect on perceived quality H2b: User generated content evaluation has a positive effect on perceived quality

According to Yoo and Donthu (2001) brand loyalty indicates the motivation to be loyal to a brand and reflect that consumers choose the brand as first choice. Advertising spending is positively related to brand loyalty because it can strengthen the association of brand and attitude toward the brand. Likewise, in social media Bruhn et al. (2013) says that the quality of interaction in brand communities like brand fan pages on facebook has a positive impact on the benefits of functional, experiential and symbolic brand communities, increasing brand loyalty. Therefore, the researcher assumes that there is influence between firm created content and brand loyalty. For user generated content, Christodoulides e t al., (2012) assumes that this form of UGC communication is closely related to brand loyalty because consumers receive messages / content provided as credible and reliable sources of information. Research conducted by Schivinski \& Dabrowski (2015) shows that there is a positive impact between user generated content and brand loyalty. Therefore, the third hypothesis in this study is as follows:

H3a: Firm-created Content positively affects brand loyalty H3b: User generated content positively affects brand loyalty

In this study, researchers also want to see the relationship between dimensions in customer-based brand equity. According to research conducted by Schivinski \& Dabrowski (2015) there is a significant influence between brand awareness / association on brand loyalty and perceived quality but according to Bashir \& Job (2017), brand awareness / association only affects perceived quality. According to theory, the process of building customer-based brand equity begins by increasing consumer awareness of the brand and causing the creation of brand association of the brand. If consumers know about the brand and try to find more information about the brand, it will cause associate in their mind, it will affect their perception on brand quality and attitudinal brand loyalty (Aaker, 1991). So, the fourth and fifth hypothesis in this study are as follows:

H4: Brand Awareness / brand association has a positive effect on perceived quality H5: Brand awareness / brand association positively affects brand loyalty

From the above explanation, the research model can be described as follows: 
INOBIS: Jurnal Inovasi Bisnis dan Manajemen Indonesia

Volume 2, Nomor 1, Desember 2018

Vinna Hermaren; Adrian Achyar

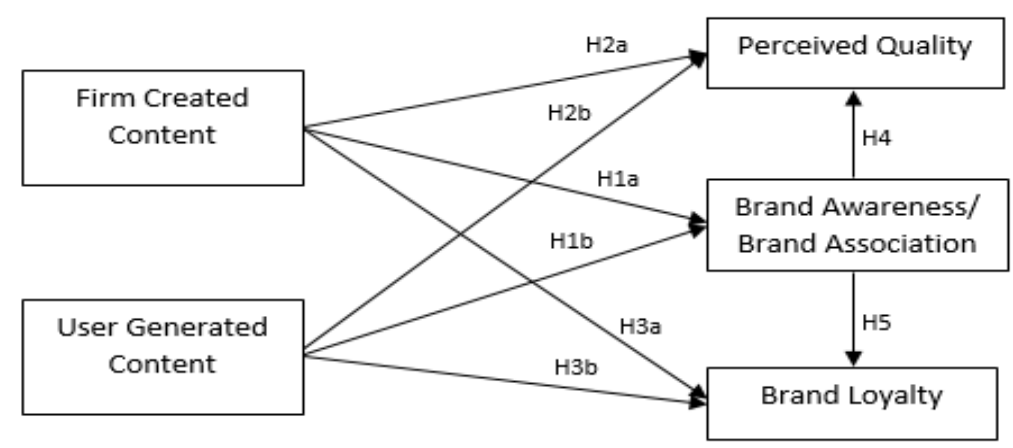

\section{Methodology}

In this study, researchers have conducted a mini survey to find out local cosmetic brands that do promotion only through social media to 30 respondents. Research is limited to brands that only do promotion in social media to see social media linkage to brand awareness. A total of $23 \%$ of respondents most often mention the brand Emina Cosmetics. Further mini survey also conducted to see social media platform used by respondent. From the data known that the most widely accessed social media is Instagram that is equal to $63.3 \%$. Therefore, the type of social media that will be used in this research is Instagram. In addition, researchers will also use facebook as a social media platform because facebook includes the most used social media platform in the world (Dunn, 2017).

To collect the data, this research used a standardized online survey on Instagram and Facebook. Links to surveys are done via direct messages to brand fan respondents on instagram or facebook to invite respondents to take part in this research. The invitation to the survey informed about the topic of the study. To ensure that respondents distinguish between two social media communications, the researcher gives a short sample of each type. The procedure is performed by data filtering and univariate outlier detection. During this phase, twenty six questionnaires were excluded from the analysis, resulting in a total of 114 valid questionnaires. The questionnaire is given in Bahasa. To make sure that the original item is correctly translated, the researcher use the re-translation process.

All questions in the survey are identical to the original version of the Schivinski \& Dabrowski (2015) journal except for the brand name and measured using a 5-point Likert scale, ranging from 1 as "strongly disagree" to 5 as "strongly agree".

Data processing questionnaire using SPSS software for pretest and Lisrel for main test. Researchers conducted descriptive research to test the reliability and validity of the data obtained during the pre-test and main test and Structural Equation Model (SEM) analysis methods to answer the research hypothesis that has been prepared.

\section{Findings}

There are two dimensions of brand communication in social media which will be discussed in this research that is firm created content and user generated content which will be seen its influence to three dimension of brand equity, namely: brand awareness / association, perceived quality and brand loyalty. 
INOBIS: Jurnal Inovasi Bisnis dan Manajemen Indonesia

Volume 2, Nomor 1, Desember 2018

Vinna Hermaren; Adrian Achyar

\subsection{Model Fitting Information}

The steps involved in this approach are (1) Validity test, (2) Reliability test, and (3) measurement of goodness of fit.

\begin{tabular}{|c|c|c|c|c|c|}
\hline \multicolumn{6}{|c|}{ Test Validity and Reliability } \\
\hline Variable & Indicator & $\begin{array}{c}\text { Error } \\
\text { Variance }\end{array}$ & $\begin{array}{c}\text { Standardized } \\
\text { Loading } \\
\text { Factor }\end{array}$ & $\begin{array}{l}\text { Construct } \\
\text { Reliability } \\
(C R \geq 0.7) \\
\end{array}$ & $\begin{array}{c}\text { Variance } \\
\text { Extracted }(V E \\
\geq 0.5)\end{array}$ \\
\hline \multirow[t]{4}{*}{ Firm Created Content } & FC1 & 0,35 & 0,80 & \multirow{4}{*}{0.864923} & \multirow{4}{*}{0.615819} \\
\hline & FC2 & 0,32 & 0,82 & & \\
\hline & FC3 & 0,43 & 0,75 & & \\
\hline & FC4 & 0,43 & 0,76 & & \\
\hline \multirow{4}{*}{$\begin{array}{l}\text { User Generated } \\
\text { Content }\end{array}$} & UG1 & 0,30 & 0,84 & \multirow{4}{*}{0.891452} & \multirow{4}{*}{0.672664} \\
\hline & UG2 & 0,29 & 0,84 & & \\
\hline & UG3 & 0,32 & 0,82 & & \\
\hline & UG4 & 0,40 & 0,78 & & \\
\hline \multirow{4}{*}{$\begin{array}{c}\text { Brand Awareness/ } \\
\text { Association }\end{array}$} & BAS1 & 0,32 & 0,83 & \multirow{4}{*}{0.902148} & \multirow{4}{*}{0.697455} \\
\hline & BAS2 & 0,27 & 0,85 & & \\
\hline & BAS3 & 0,29 & 0,84 & & \\
\hline & BAS4 & 0,33 & 0,82 & & \\
\hline \multirow[t]{3}{*}{ Perceived Quality } & PQ1 & 0,32 & 0,82 & \multirow{3}{*}{0.843338} & \multirow{3}{*}{0.642236} \\
\hline & PQ2 & 0,40 & 0,78 & & \\
\hline & PQ3 & 0,35 & 0,80 & & \\
\hline \multirow[t]{3}{*}{ Brand Loyalty } & BL1 & 0,14 & 0,92 & \multirow{3}{*}{0.889231} & \multirow{3}{*}{0.728997} \\
\hline & BL2 & 0,26 & 0,86 & & \\
\hline & BL3 & 0,41 & 0,77 & & \\
\hline \multicolumn{6}{|c|}{$\begin{array}{l}\text { Goodness of Fit } \\
\end{array}$} \\
\hline $\begin{array}{c}\text { Size of Goodness of } \\
\text { Fit (GOF) }\end{array}$ & Ideal $\mathrm{M}$ & atch Rate & Estimated Re & lits & Match Rate \\
\hline \multicolumn{6}{|c|}{ Absolute Fit Measure } \\
\hline $\begin{array}{c}\text { Statistic Chi-Square } \\
(X 2)\end{array}$ & \multicolumn{2}{|c|}{$\mathrm{p}>0.05$} & \multicolumn{2}{|c|}{$250.82(\mathrm{P}=0.00)$} & Good Fit \\
\hline $\begin{array}{c}\text { Non-Centraly } \\
\text { Parameter }(N C P)\end{array}$ & \multicolumn{2}{|c|}{$\begin{array}{c}\text { Interval (181.07; } \\
294.54)\end{array}$} & \multicolumn{2}{|l|}{124.82} & Good Fit \\
\hline $\begin{array}{l}\text { Goodness of Fit Index } \\
(\text { GFI) }\end{array}$ & \multicolumn{2}{|c|}{$0.80 \leq \mathrm{GFI}<0.90$} & \multicolumn{2}{|l|}{0.80} & Marginal Fit \\
\hline $\begin{array}{c}\text { Standardized Root } \\
\text { Mean Square Residual }\end{array}$ & \multicolumn{2}{|c|}{$\mathrm{SRMR} \geq 0.05$} & \multicolumn{2}{|l|}{0.099} & Poor Fit \\
\hline $\begin{array}{c}\text { Root Mean Square } \\
\text { Error of Approximation } \\
\text { (RMSEA) }\end{array}$ & $\begin{array}{r}0.05<1 \\
0\end{array}$ & MSEA $\leq$ & 0,094 & & Marginal Fit \\
\hline $\begin{array}{l}\text { Expected Cross- } \\
\text { Validation Index } \\
(E C V I)\end{array}$ & $\begin{array}{r}\text { Appr } \\
\text { Saturate } \\
1 \\
\end{array}$ & $\begin{array}{l}\text { d EChing } \\
44\end{array}$ & 3.02 & & Good Fit \\
\hline & & ncremental & Fit Measure & & \\
\hline Non-Normed Fit Index & NNF & $\geq 0.90$ & 0.95 & & Good Fit \\
\hline
\end{tabular}


INOBIS: Jurnal Inovasi Bisnis dan Manajemen Indonesia

Volume 2, Nomor 1, Desember 2018

Vinna Hermaren; Adrian Achyar

\begin{tabular}{|c|c|c|c|}
\hline$(N N F I)$ & & & \\
\hline $\begin{array}{l}\text { Normed Fit Index } \\
(N F I)\end{array}$ & $\mathrm{NFI} \geq 0.90$ & 0,93 & Good Fit \\
\hline $\begin{array}{l}\text { Adjusted Goodness of } \\
\text { Fit Index (AGFI) }\end{array}$ & $0.80 \leq \mathrm{AGFI} \leq 0.90$ & 0,73 & Poor Fit \\
\hline $\begin{array}{l}\text { Relative Fit Index } \\
(\text { RFI })\end{array}$ & $0.80 \leq \mathrm{RFI} \geq 0.90$ & 0.91 & Good Fit \\
\hline $\begin{array}{l}\text { Incremental Fit Index } \\
\text { (IFI) }\end{array}$ & IFI $\geq 0.90$ & 0.96 & Good Fit \\
\hline $\begin{array}{l}\text { Comparative Fit Index } \\
\text { (CFI) }\end{array}$ & $\mathrm{CFI} \geq 0.90$ & 0.96 & Good Fit \\
\hline \multicolumn{4}{|c|}{ Parsimonius Fit Measure } \\
\hline $\begin{array}{l}\text { Parsimonious } \\
\text { Goodness of Fit Index } \\
\text { (PGFI) }\end{array}$ & $\mathrm{PGVI} \geq 0.50$ & 0.59 & Good Fit \\
\hline $\begin{array}{l}\text { Akaike Information } \\
\text { Criterion }(A I C)\end{array}$ & $\begin{array}{c}\text { Saturated AIC }= \\
342.00\end{array}$ & $\begin{array}{c}\text { Model AIC = } \\
340.82 \\
\text { Independence AIC } \\
=3852.20\end{array}$ & Good Fit \\
\hline $\begin{array}{l}\text { Consistent Akaike } \\
\text { Information Criterion } \\
(\text { CAIC) }\end{array}$ & $\begin{array}{c}\text { Saturated CAIC }= \\
980.89\end{array}$ & $\begin{array}{c}\text { Model CAIC = } \\
508.94 \\
\text { Independence } \\
\text { CAIC }=3919.45\end{array}$ & Good Fit \\
\hline
\end{tabular}

(1) Validity Test

The validity test of the measurement model using the LISREL 8.8 program will see the variance error and the standardized loading factor shown in the model. Each indicator must meet the requirements of error variance and standardized loading factor $\geq 0.50$. From the data can be seen that all the variables and indicator questions declared valid because the value is greater than 0.50 .

(2) Reliability Test

Reliability construct test using composite reliability measure, and variance extracted measure. The reliability of the construct is considered good if the value of construct reliability $\geq 0.70$ and the value of variance extracted $\geq 0.50$. From the data it is known that all variables have a construct reliability value greater than 0.70 and the value of variance extracted is greater than 0.50 , so that research can proceed to the next step to test the overall fit of the model.

\section{(3) Goodness of Fit Test}

The results showed good model match rate. The researchers concluded that the model used in the study included in the category of good fit. Research with good fit category shows that the research model used can well measure the relationship between latent variables with observed variables. 
INOBIS: Jurnal Inovasi Bisnis dan Manajemen Indonesia

Volume 2, Nomor 1, Desember 2018

Vinna Hermaren; Adrian Achyar

\subsection{Structural Model Analysis Results}

Assessment of structural models can be used to see the relationships between variables that fit the conceptual framework. The following is the calculation of latent relationship variable that has been calculated:

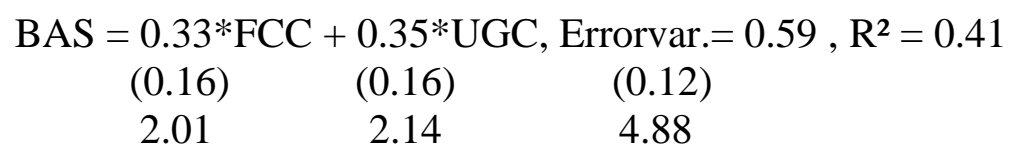

$\begin{array}{cccc}\mathrm{BL}=0.23 * \mathrm{BAS} & +0.43 * \mathrm{FCC} & -0.25 * \mathrm{UGC}, \text { Errorvar. }=0.82, \mathrm{R}^{2}=0.18 \\ (0.13) & (0.19) & (0.19) & (0.14) \\ 1.75 & 2.21 & -1.33 & 5.76\end{array}$

$\begin{array}{cccc}\mathrm{PQ}= & 0.22 * \mathrm{BAS}+0.37 * \mathrm{FCC}+ & 0.38 * \mathrm{UGC}, \text { Errorvar. }=0.25, \mathrm{R}^{2}=0.75 \\ (0.095) & (0.14) & (0.14) & (0.071) \\ 2.33 & 2.74 & 2.79 & 3.44\end{array}$

Hypothesis 1a examines the effect of firm created content on brand awareness / association on Emina Cosmetics, has t-value (2.01) > t-table (1.96) so hypothesis 1a is accepted. Hypothesis $1 \mathrm{~b}$ examines the effect of user generated content on brand awareness / association on Emina Cosmetics, has a t-value of 2.14>t-table (1.96) so that hypothesis $1 \mathrm{~b}$ is accepted. Hypothesis $2 \mathrm{a}$ examines the effect of firm created content on perceived quality on Emina Cosmetics, has a t-value of 2.74> t-table (1.96) so that hypothesis $2 \mathrm{a}$ is acceptable. Hypothesis $2 b$ examines the effect of user generated content on perceived quality on Emina Cosmetics, has a t-value of 2.79> t-table (1.96) so that hypothesis $2 \mathrm{~b}$ is acceptable. Hypothesis $3 \mathrm{a}$ examines the effect of firm created content on brand loyalty on Emina Cosmetics, has a t-value of 2.21> t-table (1.96) so that hypothesis 3a is acceptable. Hypothesis $3 \mathrm{~b}$ examines the effect of user generated content on brand loyalty on Emina Cosmetics, has a t-value of $-1.33<\mathrm{t}$-table (1.96) so that hypothesis $3 \mathrm{~b}$ is rejected. Fourth hypothesis tested the effect of brand awareness / association on perceived quality on Emina Cosmetics, having a t-value of 2.33> t-table (1.96) so that hypothesis four is acceptable. The fifth hypothesis testing the effect of brand awareness / association on brand loyalty on Emina Cosmetics, has a t-value of $1.75<\mathrm{t}$-table (1.96) so that the five hypothesis is rejected.

\subsection{Discussion}

\section{Test Result Influence Evaluation Firm Created Content and User Gnerated Content to Brand Awareness / Association on Emina Cosmetics}

Based on the results of research known that consumer evaluation of firm created content in social media can influence brand awareness / association of a brand. This result is in line with research conducted by Hutter et al., (2013) where there is a strong correlation between consumer engagement and brand fan page in social media and their perception of brand awareness. The relationship of these influences is positive in accordance with the studies undertaken by Bruhn, Schoenmueller, \& Schäfer (2012), Schivinski \& Dabrowski (2015), Bashir, Job, \& Jalees (2017), and Grubor et al. (2017). Positive influence means that the better 
INOBIS: Jurnal Inovasi Bisnis dan Manajemen Indonesia

Volume 2, Nomor 1, Desember 2018

Vinna Hermaren; Adrian Achyar

the evaluation of firm created content in social media will be the higher awareness / association of consumers to the brand.

Brand awareness with strong associations will form a specific brand image (Yoo et al., 2000). In practice, through social media communication Emina Cosmetics is able to grow a strong brand association in the minds of consumers through the contents created in social media Emina Cosmetics official who describes the playful and fun impression. Content is also created with a selection of bright colors favored by adolescent women such as pink, blue, yellow, and so forth, making it easier to remember consumers. Content is also made by utilizing several artists as brand ambassadors such as Isyana Sarasvati and Nasya Marcella.

When viewed from the results of research hypothesis $1 \mathrm{~b}$ known that there is influence evaluation user generated content to brand awareness / association. This is in accordance with research conducted by Bruhn, Schoenmueller, \& Schäfer (2012), Schivinski \& Dabrowski (2015), Bashir, Ayub, \& Jalees (2017), and Khajuria (2017). This influence is positive which means the better evaluation of user generated content in social media, the higher the awareness and the consumer association of the brand.

Social media users such as Instagram and facebook who use Cosmetic products are happy to share their experiences in social media about the quality of Cosmetic products. This is also done by users who have used Emina Cosmetic products and connected with social media Emina Cosmetic official. Share this experience is done by directly tag Emina Cosmetic official so that follower or friends who follow social media user can see the content created by user which then raises awareness to Emina Cosmetic brand. Users who have been aware of the Emina brand and are interested in the content created by the users that they follow, the user will seek more information about Emina's products by directly visiting Emina Cosmetic's website or social media or looking for reviews about Emina's products through blogs and youtube. The data obtained showed that $77.2 \%$ of respondents said they saw Emina Cosmetic review through Instagram, 1.8\% through facebook, 9.6\% through Instagram and facebook, $7 \%$ via youtube, and the rest saw Emina Cosmetic review through blog and product review on line.

From the description above, it can be concluded that brand evaluation in social media both firm created content and user generated content can build brand awareness / association of consumers on the brand in the cosmetics industry, especially Emina Cosmetics brand.

\section{Test Result Influence Evaluation Firm Created Content and User Generated Content to Perceived Quality on Emina Cosmetics}

Based on the results of research, it is known that the evaluation of firm created content in social media can influence consumer perceptions of the quality of a brand. The relationship of this influence is positive which means the better the evaluation of firm created content in social media, the higher the consumer perception of the quality of Emina Cosmetics. The results of this study are in accordance with Bashir \& Job (2017) and Grubor et al. (2017) where there is a positive and significant correlation between firm created content and perceived quality.

The same is true for evaluation of user generated content. There is a positive and significant influence between the evaluation of user generated content in social media and perceived quality. This study is in accordance with research Schivinski \& Dabrowski (2015) is in brand communication in social media, user generated content evaluation has a positive impact on perceived quality. Consumers who have been aware of the Emina brand will be looking for more information about Emina's products through reviews on Instagram, 
INOBIS: Jurnal Inovasi Bisnis dan Manajemen Indonesia

Volume 2, Nomor 1, Desember 2018

Vinna Hermaren; Adrian Achyar

facebook, blog, line, and youtube. With the increasing number of information obtained by consumers regarding Emina products, it will affect consumer perceptions of the quality of Emina Cosmetic brand.

\section{Test Result Influence Evaluation Firm Created Content and User Generated Content to Brand Loyalty on Emina Cosmetics}

Based on the results of the research, it is known that the evaluation of firm created content can influence consumer loyalty to the brand. This is in line with research conducted by Bruhn et al. (2013) which says that the quality of interaction in brand communities such as brand fan pages on social media has a positive impact on the benefits of functional, experiential and symbolic brand communities, increasing brand loyalty. The same is mentioned in the study of Grubor et al. (2017) which states that firm created social media communication positively and significantly influence toward behavioral loyalty. Perceptions of social media marketing activities are the main drivers of brand loyalty because followers of brand pages in social media tend to be loyal and committed to brands (Ismail, 2017). In the study, the positive effect indicates that the better the evaluation of firm created content created in Emina Cosmetic official social media, the higher the consumer loyalty to the Emina Cosmetic brand.

In practice, consumers are satisfied with the posting of Emina Cosmetics in social media official such as facebook and Instagram. According to consumers, the created content is very interesting and the information submitted in accordance with expectations. Although there are other brands with cheaper prices and with the same quality with Emina, but consumers still intend to become loyal customers of Emina Cosmetics.

Conversely, data on hypothesis $2 b$ is rejected, indicating that there is no significant effect between user generated content evaluation on brand loyalty. This means that evaluation of the Emina Cosmetics review on user-created social media is not able to influence consumer loyalty to the Emina Cosmetic brand. The results contradict research conducted by Schivinski \& Dabrowski (2015) and Khajuria (2017) where they say that there is a significant influence between user generated content and brand loyalty. Disagreement on the results of this study occurred because the questionnaire was not given a screening question for respondents who have seen the review of Emina Cosmetics. Limitations of this study may lead to the evaluation results of user generated content on brand loyalty is not significant.

\section{Test Result Effect of Brand Awareness / Association on Perceived Quality and Brand Loyalty}

In the dimension of customer-based brand equity, research results show that brand awareness / association is able to influence consumer perceptions of the quality of a brand. The results of this study are in accordance with Chi, Yeh, \& Yang (2009) and Gautam \& Shrestha (2016) studies that brand awareness and brand association have a positive and significant influence on perceived quality. But this research shows that brand awareness does not have a direct influence on brand loyalty. The results are in accordance with research conducted by Bashir \& Job (2017) which says that brand awareness / association only affect perceived quality. According to Aaker (1991) brand equity theory, the process of building brand equity begins with increasing consumer awareness of the brand and causing brand association to brand. If consumers know about a brand and seek to find more information about the brand, it will cause associate in their mind and affect perceptions about brand 
INOBIS: Jurnal Inovasi Bisnis dan Manajemen Indonesia

Volume 2, Nomor 1, Desember 2018

Vinna Hermaren; Adrian Achyar

quality and attitudinal brand loyalty. From this theory can be seen that the influence of brand awareness / association on brand loyalty will pass perceived quality first where with the perception of the positive quality that consumers perceive of a product, will lead to loyalty to a brand.

\section{Conclusion}

This study aims to find out how the influence of evaluation of firm created content and user generated content to customer-based brand equity. Based on the results of the analysis and discussion that has been done, it can be seen that there is a positive and significant influence between the evaluation firm created content and user generated content to brand awareness/ association. in addition, there is a positive and significant influence between the evaluation firm created content and user generated content against perceived quality. There is a positive and significant influence between firm created content evaluation on brand loyalty, but there is no positive and significant influence between evaluation of user generated content to brand loyalty. while in customer-based brand equity dimension, there is positive and significant influence between brand awareness/ association to perceived quality. However, there is no positive and significant influence between brand awareness/ association on brand loyalty.

Based on the research, the managerial implication of the researcher for Emina Cosmetics is first, the content created by Emina Cosmetics in social media was able to influence the dimension of customer-based brand equity so as to create consumer loyalty. Emina Cosmetics needs to take advantage of this opportunity by focusing on creating interesting content in the media so that it will attract more consumers especially in accordance with the target market of Emina aged 15-25 years. In addition, Emina can also create content such as make up tutorials because the 15-25 years old age segment is a new age group that is starting to learn make up so that this content will be able to create a good quality perception related to Emina Cosmetics brand. Emina can also provide an opportunity for his follower to make a video makeup tutorial that will be selected to be displayed in social media Emina Cosmetics official. This will be able to increase consumer loyalty to Emina Cosmetics.

Then, research shows that user generated content has no effect on brand loyalty, but user generated content is able to influence awareness / association and consumer perception on emina brand quality so Emina Cosmetics need to create activity to trigger user to create content. Emina Cosmetics can hold activities at various schools or colleges by inviting brand ambassador or vlogger and make up class by using Emina Cosmetics brand. With these activities, consumers will be more aware of Emina Cosmetics and they will most likely volunteer to create content related to the emina activity in social media.

\section{Limitations and directions for future studies}

In this research there are some limitations among others. First, respondents in this research mostly already know that brand Emina Cosmetics one company with Wardah and Make Over. This can lead to bias in the research because it can affect consumer answers on each variable in the study. Second, this research uses only two types of social media namely facebook and Instagram. Research does not use other social media platforms used by Emina Cosmetics to build awareness and engagement with customers like youtube and google + . And then, the researchers did not do a screening question to see the effect of user generated content evaluation because the researcher assumed that the previous respondent had seen / read the review about Emina Cosmetics in social media. With these limitations, the researcher's 
INOBIS: Jurnal Inovasi Bisnis dan Manajemen Indonesia

Volume 2, Nomor 1, Desember 2018

Vinna Hermaren; Adrian Achyar

suggestion for further research is first, for further research it is better to use respondents who do not know that Emina Cosmetics is one company with Wardah and Make Over or use another brand to get more accurate results from social media influence on brand awareness. Second, further research can measure the influence of social media communication on several other social media platforms. it is also expected in subsequent research respondents who used only those who have seen the content in social media Emina Cosmetics official and also the content / review Emina Cosmetics made by other users (added screening question whether the respondent ever saw / read reviews about Emina Cosmetics in social media).

\section{Reference}

Aaker, D. (1991). Managing Brand Equity. Capitilazing on the Value of a Brand Name. The Free Press, New York

Aaker, D.A. and Joachimsthaler, E. (2000), Brand Leadership, Building Assets in the, Free Press, New York, NY

APJII. (2016). Infografis penetrasi dan perilaku pengguna internet indonesia. Jakarta: Polling Indonesia.

Asare, I. T. (2013). Business \& Applied Sciences. International Journal of Marketing Research, 1(4).

Asur, S., \& Huberman, B. A. (2010). Predicting the Future With Social Media.

Bannister, L. (2006) User-generated content uncovered: power to the people. Available online at: http://www.brandrepublic.com/bulletins/digital/article/589413/ usergeneratedcontent-uncovered-power-people/

Bashir, M. A., Ayub, N., \& Jalees, T. (2017). The impact of the firm generated contents and the user generated contents through social media on brand equity elements. Pakistan Business Review, 744-760.

Belch, G. E., \& Belch, M. A. (2015). Advertising and Promotion : An Integrated Marketing COmmunications Perspective (Global Edi). New York: McGraw-Hill.

Bruhn, M., Schoenmueller, V., \& Schäfer, D. B. (2012). Are social media replacing traditional media in terms of brand equity creation? Management Research Review, 35(9), 770-790. https://doi.org/10.1108/01409171211255948

Cheong, H. J., \& Morrison, M. A. 2008. Consumers' Reliance on Product Information and Recommendations found in UGC. Journal of Interactive Advertising, 8(2), 1-30

Chi, H. K., Yeh, H. R., \& Yang, Y. T. (2009). The Impact of Brand Awareness on Consumer Purchase Intention: The Mediating Effect of Perceived Quality and Brand Loyalty. Journal of International Management Studies, 4(1), 135-144. https://doi.org/10.2307/3151897

Christodoulides, G. (2012). Cross-national differences in e-WOM influence. European Journal of Marketing. 46(11), 1689- 1707

Dbs. (2013). Indonesia Pasar Potensial Bagi Industri Kosmetik. Retrieved January 1, 2017, from http://indonesianconsume.blogspot.co.id/2013/03/indonesia-pasar-potensial-bagiindustri.html\#

Dean, D.H. and Biswas, A. (2001). Third-party organization endorsement of products: an advertising cue affecting consumer pre-purchase evaluation of goods and services. Journal of Advertising, 30(4), 41-57

Fournier, S. \& Avery, J. (2011). The uninvited brand. Journal of Business Horizons, 54(3), 193-207 
INOBIS: Jurnal Inovasi Bisnis dan Manajemen Indonesia

Volume 2, Nomor 1, Desember 2018

Vinna Hermaren; Adrian Achyar

Gautam, D. K., \& Shrestha, S. K. (2016). Determinants of brand equity in digital satellite television services : evidence from Dish Home of Nepal Dhruba Kumar Gautam * and Sajeeb Kumar Shrestha, 20(December 2015), 3-4.

Gil, R.B., Andrés, E.F. and Salinas, E.M. (2007). Family as a source of consumer-based brand equity. Journal of Product \& Brand Management, Vol. 16 No. 3

Godes, D., \& Mayzlin, D. (2009). Firm-Created Word-of-Mouth Communication: Evidence from a Field Test. Marketing Science, 28(4), 721-739. https://doi.org/10.1287/mksc.1080.0444

Grubor, A., Djokic, I., \& Milovanov, O. (2017). the influence of social media communication on brand equity: the evidence for environmentally friendly products. Research, 15(January), 963-983. https://doi.org/10.15666/aeer/1503

Holbrook, M. B., \& Corfman, K. P. (1985). Quality and value in the consumption experience: Phaedrus rides again. In J. Jacoby, \& J.C. Olson (Eds.), Perceived Quality: How Consumers View and Merchandise (pp.31-57). Lexington, MA: Lexington Books.

Hutter, K., Hautz, J., Dennhardt, S. and Füller, J. (2013). The impact of user interactions in social media on brand awareness and purchase intention: the case of MINI on Facebook. Journal of Product \& Brand Management. Vol. 22 No. 5, pp. 342-351.

Ismail, A. R. (2017). The influence of perceived social media marketing activities on brand loyalty. Asia Pacific Journal of Marketing and Logistics, 29(1), 129-144. https://doi.org/10.1108/APJML-10-2015-0154

Kaplan, A. M., \& Haenlein, M. (2010). Users of the world, unite! The challenges and opportunities of Social Media. Business Horizons, 53(1), 59-68. https://doi.org/10.1016/j.bushor.2009.09.003

Keller, K.L. (1993), "Conceptualizing, measuring, and managing customer-based brand equity", Journal of Marketing, Vol. 57 No. 1, pp. 1-22

Keller, K.L. (1998), Strategic Brand Management: Building, Managing and Measuring Brand Equity, Prentice Hall, NJ.

Khadim, RA. Younis, M. Mahmood, A. Khalid, R., (2015) Firm Created Social Media Communication and Consumer Brand Perception. International Journal of Marketing and Technology. 5(3), 91

Khajuria, I. (2017). A Study of User-Generated Content on Social Networking Sitesand its Impact on Consumer-Based Brand Equity Constructs. Global Journal of Management and Business Research, 17(1).

Kumar et al. (2015). From Social to Sale: The Effects of Firm Generated Contenetsin Social Media on Consumer Behavior. Journal of Marketing. (2015), 1-72

Kurniawan, I. (2013). Industri Kosmetik diprediksi tumbuh 15\%-hingga akhir 2013. Harian Ekonomi Neraca-E-Paper. Retrieved from http://www.neraca.co.id/article/32513/hingga-akhir-2013-industri-kosmetik-diprediksitumbuh-15

Malhotra, N. (2007). Marketing Research: An Applied Approach (5th ed.). New Jersey: Pearson Prentice hall.

Mangold, W.G. and Faulds, D.J. (2009), "Social media: the new hybrid element of the promotion mix", Business Horizons, Vol. 52 No. 4, pp. 357-366

Muniz, A. M. \& Schau, H. J. (2011). How to inspire value-laden collaborative consumergenerated content. Business Horizons (2011) 54, 209-217.

OECD. (2007). Participative web and user-created content: Web 2.0, wikis, and social networking. Paris: Organisation for Economic Co-Operation and Development., (2006), 74. https://doi.org/10.1787/9789264037472-en 
INOBIS: Jurnal Inovasi Bisnis dan Manajemen Indonesia

Volume 2, Nomor 1, Desember 2018

Vinna Hermaren; Adrian Achyar

Rangaswamy, Arvind, Raymond Burke, and Terence A. Oliva. (1993). Brand Equity and the Extendibility of Brand Names. International Journal of Research in Marketing, 10 (March): 61-75.

Ryan, D., \& Jones, C. (2009). Marketing strategies for engaging the digital generation.

Schivinski, B., \& Dabrowski, D. (2015). The impact of brand communication on brand equity through Facebook. Journal of Research in Interactive Marketing, 9(1), 31-53. https://doi.org/10.1108/JRIM-02-2014-0007

Tuominen, P. (1999). Managing brand equity. The Finnish Journal of Business Economics 48 (1): $65-100$

Vanden Bergh, B. G., Lee, M., Quilliam, E. T., \& Hove, T. (2011). The multidimensional nature and brand impact of user-generated ad parodies in social media. International Journal of Advertising, 30(1), 103-131. https://doi.org/10.2501/IJA-30-1-103-131

Villarejo-Ramos, A.F. and Sánchez-Franco, M.J. (2005). The impact of marketing communication and price promotion on brand equity. Journal of Brand Management. Vol. 12 No. 6, pp. 431-444.

Washburn H. Judith \& Plank E. Richard. (2002). Measuring Brand Equity: An Evaluation of a Consumer-Based Brand Equity Scale. Journal of Marketing, Theory and Practice. pp.46-61

Yoo, Boonghee; Donthu, N. (2001). Developing and Validating a Multi-dimensional CBBE scale. Journal of Business Research, 10(1), 61-67. https://doi.org/10.1016/S01482963(99)00098-3

Yoo, B., Donthu, N., \& Lee, S. (2000). An Examination of Selected Marketing Mix Elements and Brand Equity. Journal of the Academy of Marketing Science, 28(2), 195-211. https://doi.org/10.1177/0092070300282002

Zeithaml, V.A. (1988). Consumer Perceptions of Price, Quality, and Value: A Means- End Model and Synthesis of Evidence. 52 (3): 2- 22. Journal of Marketing

Zeithaml, V., Berry, L.L. and Parasuraman, A. (1996). The behavioral consequences of service quality. Journal of Marketing. Vol. 60, April, pp. 31-46 